\title{
Näkökulmia työhön ja oppimiseen yksien kansien sisällä
}

Anneli Eteläpelto, Kaija Collin \& Jaana Saarinen (toim. 2007). Työ, identiteetti ja oppiminen. WSOY.

\footnotetext{
A

Anneli Eteläpellon, Kaija Collinin ja Jaana Saarisen toimittama kirja Työ, identiteetti ja oppiminen on vahva tietopaketti työelämään liittyvästä oppimisesta tai työpaikkaoppimisesta, mitä käsitettä kirjan johdannossa käytetään. Kirjassa liikutaan oppimisen eri tasoilla ja tuotetaan monenlaisia näkökulmia aiheeseen. Tavoitteena on kirjoittajien mukaan luoda ajankohtaiseen tutkimustietoon perustuva kuva siitä, miten työn luonteen muu-
}

tos heijastuu työssä oppimiseen ja ammatillisiin identiteetteihin työssä.

Kirjan luvut on jaettu neljään osaan: Ensimmäisessä osassa tarkastellaan työtä ja työelämää oppimisen ja identiteetin rakentamisen kehyksenä ja ympäristönä. Toisessa osassa keskitytään identiteettiin ja subjektiuteen. Kolmannessa osassa puolestaan tarkastellaan työssä ja työhön oppimista. Neljäs osa taas käsittelee oppimisen tiloja ja verkostoissa tapahtuvaa oppimista.

On oletettavaa, ettei monikaan (ehkä kirjatenttiin lukevia opiskelijoita lukuun ottamatta) tule lukeneeksi koko laajaa kirjaa. Siinä määrin runsaasti artikkeleita on ja ne ovat keskenään hyvinkin erilaisia. Artikkeleilla on toki yhdistäviä piirteitäkin. Useimmat noudattavat kaavaa, jossa ensin esitellään teoriaa ja sitten empiirisiä tutkimushavaintoja. Lisäksi suurin osa artikkeleista on psykologis-kasvatustieteellisesti virittyneitä, mikä on luontevaa kirjan tematiikka huo- 
mioon ottaen. Pyrkimystä monitieteisen alustan löytämiseen kasvatustiedettä kiinnostaviin kysymyksiin edustaa kirjassa se, että kirjoittajakunnassa on myös selkeästi yhteiskuntatieteelliseen työelämän tutkimukseen profiloituvia ja tieteenalarajojen ylittämiseen tottuneita tutkijoita.

Kirja alkaa Raija Julkusen artikkelilla, joka tuo ansiokkaasti esille työelämän kehityksen megatrendejä. Verkostoja käsittelevän osuuden puolestaan aloittaa Tuula Heiskasen kirjoittama artikkeli, joka kiinnittää eri tahoilla havaittavan verkostoitumisbuumin tietoyhteiskuntadebattiin ja -kehitykseen. Maahanmuuttajaja ikäisyystematiikka muistuttavat myös, minkälaiset yhteiskunnalliset ja työelämän kehityspiirteet asettavat haasteita identiteettiasemille ja identiteettityölle.

Kirjan pohjalta voinee muodostaa kohtuullisen hyvän kuvan siitä, mitä kaikkea työn, identiteetin ja oppimisen risteysasemalta voi löytää. Kirjaa on mahdollista suositella esimerkiksi henkilölle, joka etsii itselleen sopivaa näkökulmaa työelämässä tapahtuvaan oppimiseen. Artikkelit eivät yhdistävistä piirteistä huolimatta nivoudu kovin kiinteästi toisiinsa ja toiset artikkelit osuvat tarkemmin kirjan nimen rajaamaan kenttään kuin toiset, mutta tällainen on toki artikkelikokoelmille tyypillistä. Monipuolisesta artikkelitarjonnasta löytynee kuitenkin jokaiselle työelämässä tapahtuvasta oppimisesta kiinnostuneelle mielenkiintoista luettavaa. Edellä jo mainittujen teemojen lisäksi kirjassa tarkastellaan ammatti-identiteetin muutosta kasvatustieteilijöille läheisen opettajan työn kautta ja sukupuolittuneen subjektiuden muotoutumista tutkimustyössä.

Työssä oppimista syväluodataan niin erikseen kuin yhteen kirjoitetussa muodossa. Yrityskonsultoinnista innostuneille tarjotaan työkaluksi työssä oppimisen prosessimallia ja verkostojen analysointi ja kehittäminenkin saavat tilansa. Verkostoja tarkastellaan sekä yksilön asiantuntijuuden että laajempien näkökulmien kautta. Päivi Tynjälän, Merja Ikonen-Varilan, Liisa Myyryn ja Tuija Hytösen artikkelissa "Verkostoissa oppiminen" asetetaan oppivaksi subjektiksi yksilön ohella jopa maantieteellinen alue ja yritysverkosto ja laajennetaan tätä kautta kirjan kattavuutta.

Anneli Eteläpellon artikkelista "Työidentiteetti ja subjektius rakenteiden ja toimijuuden ristiaallokossa" on luettavissa taustaviritykset kirjan kokoamiselle. Se on mielenkiintoinen ja perusteellinen esitys identiteettikäsitteen tuomasta lisäarvosta työelämää ja oppimista käsitteleville tarkasteluille. Identiteetti antaa kirjoittajan mukaan alustan yksilöllisen ja yhteisöllisen kohtaamiselle. Artikkeli pyöriikin yhteiskuntatieteellisissä peruskysymykissä ja hakee tukijalkoja muiden ainesten ohella "vanhoista hyvistä työelämän tutkimuksista”. Erityisesti subjektin ja toimijuuden käsittelyn kohdal- la kirjoittaja pyrkii omien sanojensa mukaan ottamaan etäisyyttä kasvatustieteen perinteeseen, joka tyytyy suppeaan subjektiin.

\section{Koonta on jätetty tekemättä}

Eteläpellon ym. toimittaman kirjan lopetus on jossain määrin yllättävä. Usein artikkelikokoelmien yhtenäisyyttä pyritään lisäämään ja sanomaa selkiyttämään jonkinlaisella yhteenvetotai johtopäätösluvulla. Syystä tai toisesta tällainen puuttuu arvioitavana olevasta kirjasta. Viimeisen artikkelin luettuani jäin miettimään, mitä kirjan toimittajat olisivat loppusanoissaan lukijoille kertoneet, jos he olisivat sellaiset kirjoittaneet. Kenties niissä olisi voinut palata johdannossa esitettyyn tavoitteenasetteluun ja kertoa yhteenvetona, millaisilta työssä oppiminen ja ammatilliset identiteetit kirjan artikkeleissa kuvattujen työn luonteen muutosten valossa kiteytetysti näyttävät. Tällainen analyyttinen luonnehdinta olisi ollut arvokas niin kasvatustieteilijöille kuin työelämän tutkijoillekin, puhumattakaan sen käyttökelpoisuudesta erilaisille politiikkatoimijoille.

\section{ANU JÄRVENSIVU}

